\title{
Energy-economic analysis and environmental impacts of greenhouse crops (cucumber and tomato) production using life cycle assessment approach (case study: Tehran province, Iran)
}

Amirhossein Ahmadbeyki

Islamic Azad University of Tehran: Islamic Azad University Central Tehran Branch

Mohammad Ghahderijani (D Ghahderijani@srbiau.ac.ir)

Islamic Azad University of Tehran: Islamic Azad University Central Tehran Branch

Alimohammad Borghaee

Islamic Azad University of Tehran: Islamic Azad University Central Tehran Branch

Hossein Bakhoda

Islamic Azad University of Tehran: Islamic Azad University Central Tehran Branch

\section{Research Article}

Keywords: Energy ratio, Energy productivity, Life cycle assessment, Cumulative exergy demand

Posted Date: January 25th, 2022

DOI: https://doi.org/10.21203/rs.3.rs-1161688/v1

License: (c) (1) This work is licensed under a Creative Commons Attribution 4.0 International License.

Read Full License 
Title:

Energy-economic analysis and environmental impacts of greenhouse crops (cucumber and tomato) production using life cycle assessment approach (case study: Tehran province, Iran)

\begin{abstract}
Authors:
Amirhossein Ahmadbeyki ${ }^{a}$, Mohammad Ghahderijani ${ }^{{ }^{*},}$, Alimohammad Borghaee ${ }^{\text {a }}$, Hossein Bakhoda $^{\mathrm{a}}$
\end{abstract}

\title{
Affiliation:
}

${ }^{a}$ Department of Agricultural Systems Engineering, Science and Research Branch, Islamic Azad University, Tehran, Iran.

*Corresponding authors: Mohammad Ghahderijani (

\section{Complete Postal Address:}

Department of Agricultural Systems Engineering, Science and Research Branch, Islamic Azad University, Tehran, Iran.

Tel: +989128995894 


\title{
Energy-economic analysis and environmental impacts of greenhouse crops (cucumber and tomato) production using life cycle assessment approach \\ (Case study: Tehran province, Iran)
}

\begin{abstract}
Considering the energy consumption per unit area of the greenhouse industry, the study of energy consumption and energy indicators is one of the goals of this research. The results of cucumber input and output energy were 405405.75 $\mathrm{MJ} \mathrm{ha}{ }^{-1}$ and 104982.94 MJ ha-1, respectively. Subsequently, the input (412911.99 $\mathrm{MJ} \mathrm{ha}^{-1}$ ) and output (228281.37 $\mathrm{MJ} \mathrm{ha}^{-1}$ ) energies of the tomato were also calculated. Diesel fuel had the largest share of energy consumption in the production of cucumber and tomato to more than $60 \%$. Energy ratio $<1$, energy productivity $<1$, specific energy $>1$ and net energy gain $<0$ were obtained. LCA method was used to review and compare the publications of the studied products. The results of ReCiPe method showed that the categories of resources, human health and ecosystems were ranked first to third in terms of environmental emissions, respectively. The highest environmental publications are on-greenhouse emissions, diesel fuel and electricity with a share of about 80, 70 and 15 percent, respectively. Emissions from tomato production were lower than cucumber production in all classification groups. The cumulative exergy demand method examined the forms of renewable and non-renewable energies. Non-renewable, fossil form had a significant share for cucumber (2802.88 $\left.\mathrm{MJ} \mathrm{ton}^{-1}\right)$ and tomato (1301.14 $\mathrm{MJ}$ ton $\left.^{-1}\right)$. In various forms of renewable and non-renewable energy, chemical fertilizers were more effective than other inputs.
\end{abstract}

Keywords: Energy ratio, Energy productivity, Life cycle assessment, Cumulative exergy demand 


\section{Introduction}

The use of modern methods and the optimal use of existing arable land is one of the few solutions for preparing human food in the future. Therefore, food production should be commensurate with population growth (Khoshnevisan et al. 2013). In the future, it will be a sustainable and successful production that consumes less energy with more production (Canakci and Akinci 2006). The producer goal of the agricultural sector is determined by environmental, geographical and economic conditions (Ghorbani et al. 2011). In greenhouse conditions, more production is achieved by favoring the culture medium and consuming more energy at a lower level (Khoshnevisan et al. 2013). Another advantage of this method is the off-season production. This advantage has made the farmer spend a lot of resources (money and energy). The main disadvantage of this method is the excessive consumption of energy by manufacturers (Yuan et al. 2018).

Cucumber is one of the most popular products in Iran. This product has excellent potential for cultivation in greenhouses. Greenhouse cucumbers have a beautiful appearance and thick green skin. But the main problem of greenhouse cucumbers is the strong toxins that are applied to these products (Mohammadi and Omid 2010). Tomatoes and their products are among the most popular and profitable products in the world. Therefore, the species considered in tomato cultivation correspond to the type of consumption (Esengun et al. 2007). In most parts of the world, greenhouse owners harvest tomatoes twice a year using the right temperature control and high light supply. Conditions inside the greenhouse must be carefully managed so that various factors do not cause plant disease (Esengun et al. 2007). One of the most important reasons for setting up a tomato and cucumber greenhouse is its economy. Although setting up a greenhouse requires a significant initial cost, multi-stage harvesting and short harvest time can be considered as its advantages (Khoshnevisan et al. 2014a). 1585380 tons of cucumbers and 214383 tons of tomatoes were reported in Iranian 
greenhouses with yields of 243 and 275 tons per hectare for cucumbers and tomatoes, respectively (Ministry of Jihad-e-Agriculture of Iran 2020).

The global greenhouse production system has caused significant changes in the pattern of energy consumption in the agricultural sector due to its greater dependence on fertilizers and chemical pesticides (Gallego et al. 2011). As a result, these issues are more dependent on fossil energy sources. Due to the limited resources of fossil energy, the issue of fossil energy instability is raised. Therefore, there is an important challenge regarding the sustainability of greenhouse production (Reganold et al. 2001). The study of energy consumption patterns is much needed due to the limitation of natural resources and the effects of misuse of various energy sources on human health and the environment (Mousavi-Avval et al. 2011). Examining the ratio of output and input energy depends on the type of product and material used in production. Energy analysis plays an essential role in the sustainability of production, economic optimization of the system, preservation of fossil fuel reserves and reduction of air pollution by identifying the existing shortcomings (Ozkan et al. 2011). Due to the large investments for the greenhouse, lack of proper management will reduce productivity and increase costs. Economic index evaluation should be done in a systematic and comprehensive framework (Esengun et al. 2007).

Globally, carbon dioxide $\left(\mathrm{CO}_{2}\right)$, methane $\left(\mathrm{CH}_{4}\right)$ and nitrous oxide $\left(\mathrm{N}_{2} \mathrm{O}\right)$ are the most important greenhouse gases produced by human activities. The heat and electricity sectors generate about $25 \%$ of total greenhouse gases, followed by agriculture and industry, which account for $24 \%$ and $21 \%$ of pollution, respectively (Edenhofer 2015). Product and commodity has a life cycle that begins with product design and development. Then resource extraction, product manufacturing, sorting, consumption, recycling and landfilling of waste continue (Brentrup et al. 2004; Longo et al. 2017). An implementation framework known as life cycle assessment (LCA) is used to estimate environmental pollutions ((SAIC) 2006). 
Combining the protection of natural environments with human health and the use of perspective into the life cycle leads to improved food compatibility with the environment (Nemecek et al. 2007). The LCA is known by calculating and evaluating the two components of resource consumption and emissions of various pollutants. However, in order to further protect the environment, technological advances, quality and the use of modern methods in various fields are needed (Guinée 2002).

Proper use of energy in all consumer sectors can lead to sustainable production, economic production, reducing fossil fuel consumption and preventing air pollution. Therefore, energy management is the only and closest way to make the most of available resources and fuels (Dewulf et al. 2007). In fact, reducing energy consumption, using renewable energy sources, efficient use of materials, reuse and recycling of materials and control of pollutants contribute to the sustainability of production. The study of energy from the perspective of cumulative exergy demand (CExD) can play an important role in greenhouse production (Bösch et al. 2007). Table 1 shows the energy, economic and environmental studies of different products. Each of the reports was done in different parts of the world.

Due to energy consumption to control various factors and improve environmental conditions in the production of greenhouse cucumbers and tomatoes, more energy is consumed. For this reason, it is necessary to study the flow of energy and identify the factors that lead to increased energy consumption. Given the above, the main purpose of the present study for energy analysis is to estimate the total energy produced, the inputs energy in the two greenhouse systems and related indicators. Considering the excessive consumption of cucumbers and tomatoes in Iran and the need to produce it on a very large scale, there is a need to finance greenhouses. In the following, by calculating the incomes and growth costs of the two products in greenhouses, the discussion of profitability and productivity will be mentioned. On the other hand, higher consumption of fossil fuels and greenhouse structure 
leads to a significant increase in pollutant emissions in greenhouse cultivation compared to field cultivation. Therefore, environmental assessment of greenhouse production is essential to identify important sources of energy consumption and emissions.

\begin{tabular}{|c|c|c|c|c|c|}
\hline \multicolumn{6}{|l|}{$\begin{array}{l}\text { Table1 } \\
\text { Review t }\end{array}$} \\
\hline Reference & Case study & Location & Energy & LCA & Hotspot \\
\hline Canakci and Akinci, (2006) & Vegetable & Turkey & $\nabla$ & 区 & Wood material \\
\hline Ali et al. (2017) & Cucumber & Pakistan & $\nabla$ & $\nabla$ & Fertilizer \& machinery \\
\hline Ali et al. (2017) & Tomato & Pakistan & $\nabla$ & $\nabla$ & Fertilizer \\
\hline Pishgar-Komleh et al. (2011) & Cucumber & Iran & $\nabla$ & 区 & Diesel fuel \& electricity \\
\hline Ozkan et al. (2011) & Tomato & Turkey & 可 & 区 & Fertilizer \& electricity \\
\hline Hatirli et al. (2006a) & Tomato & Turkey & $\nabla$ & 凶 & Diesel \& fertilizer \\
\hline Paramesh et al. (2018) & Arecanut & India & $\square$ & $\nabla$ & Human labor \& irrigation \\
\hline Ozkan et al. (2004) & Citrus & Turkey & $\nabla$ & 区 & Fertilizer \& diesel \\
\hline Zarei et al. (2019) & Cucumber \& tomato & Iran & 国 & $\square$ & Diesel fuel \& natural gas \\
\hline Vinyes et al. (2017) & Apple \& peach & Spain & $\mathbf{x}$ & $\nabla$ & Fruit losses \\
\hline Bosona and Gebresenbet, (2018) & Tomato & Sweden & 可 & $\nabla$ & Packaging \& drying \\
\hline Martin-Gorriz et al. (2014) & Fruit \& vegetable & Spain & 区 & $\square$ & Fertilizer \\
\hline Sanjuan et al. (2005) & Orange & Spain & $\nabla$ & $\nabla$ & Pesticides \\
\hline Mouron et al. (2006) & Apple & Switzerland & 凶 & $\nabla$ & Machinery \& pesticides \\
\hline Mohammadi-Barsari et al. (2016) & Watermelon & Iran & $\nabla$ & $\nabla$ & Machinery \\
\hline Khoshnevisan et al. (2014a) & Strawberry & Iran & $\nabla$ & $\nabla$ & Chemical fertilizer \\
\hline Present study & Cucumber \& Tomato & Iran & प & $\square$ & Diesel \& fertilizer \\
\hline
\end{tabular}

\section{Methodology}

\subsection{Data collection site}

Data from this study were collected from greenhouse owners in Tehran province $\left(35^{\circ} 42^{\prime} \mathrm{N}\right.$, $51^{\circ} 19^{\prime} \mathrm{E}$ ) of Iran using a questionnaire. Tehran is the most populous province and capital of Iran. Sample size for greenhouse cucumber and tomato production was calculated for energy, economic and environmental analyzes using Equation 1 (Cochran 1977). Information about Equation 1 and the condition of greenhouses in Tehran province is reported in Table 2 (Cochran 1977; Ministry of Jihad-e-Agriculture of Iran 2020). 


$$
n=\frac{\frac{z^{2} p q}{d^{2}}}{1+\frac{1}{N}\left(\frac{z^{2} p q}{d^{2}}-1\right)}
$$

Table 2

Information about Cochran's formula and greenhouses in Tehran province.

\begin{tabular}{lcc}
\hline Factor & Description & Amount \\
\hline$N$ & Number of target population & 120 \\
$z$ & Reliability coefficient & 1.96 \\
$p \& q(1-p)$ & Estimated ratio of attributes & 0.5 \\
$d$ & Permitted error ratio deviation & 0.05 \\
Greenhouse area (ha) & Equivalent to 21\% of the country's greenhouse area & 2038 ha \\
Number of active greenhouses & Equivalent to 12\% of active greenhouses in the country & 2476 \\
The amount of greenhouse products (ton) & Equivalent to 30\% of the country's products & 467000 ton \\
\hline
\end{tabular}

\subsection{Energy analysis method}

Energy has different forms and all its forms have the capacity to do work. Energy is divided into two types: direct (DE) and indirect (IDE). DE is used directly for agricultural activities. Human labor, diesel fuel and electricity are among the direct sources of energy (Alam et al. 2005). IDE is a type of energy that was used before the greenhouse to produce inputs. Energy used to produce machinery, chemical fertilizers, biocides and seeds are among the indirect sources of energy (Singh et al. 2002). Each of two types of direct and indirect energy is divided into two types: renewable (RE) and non-renewable (NRE). RE is produced or converted in a short time. Human labor energy and seed energy are among the renewable energy sources (Heydari et al. 2015). NRE is not produced or converted in the short term. Fossil fuels energy, biocides energy, chemical fertilizers energy and agricultural machinery energy are among the non-renewable energy sources (Dalgaard et al. 2001). 


\subsubsection{Energy equivalent of inputs and outputs}

The energy equivalent is considered as the energy content for each of the inputs and outputs (Ali et al. 2017). Energy and input-output coefficients in different greenhouse cucumber and tomato production operations were calculated as follows:

- Amount of human labor consumption (h) $\times 1.96$ (Kaab et al. 2019).

- Amount of diesel fuel $\mathrm{r}$ consumption (L) $\times 56.31$ (Nabavi-Pelesaraei et al. 2016).

- Amount of agricultural machinery consumption $(\mathrm{kg}) \times 142.70$ (Unakitan et al. 2010).

- Amount of chemical fertilizers (nitrogen) consumption $(\mathrm{kg}) \times 66.14$ (Unakitan et al. 2010).

- Amount of chemical fertilizers (phosphate) consumption $(\mathrm{kg}) \times 12.44$ (Unakitan et al. 2010).

- Amount of chemical fertilizers (potassium) consumption $(\mathrm{kg}) \times 11.15$ (Unakitan et al. 2010).

- Amount of biocides consumption $(\mathrm{kg}) \times 120$ (Ozkan et al. 2007).

- Amount of electricity consumption $(\mathrm{kWh}) \times 12$ (Ghasemi-Mobtaker et al. 2020).

- Amount of cucumber seed consumption $(\mathrm{kg}) \times 1$ (Khoshnevisan et al. 2014a).

- Amount of tomato seed consumption $(\mathrm{kg}) \times 1$ (Taki et al. 2013).

- Amount of cucumber consumption $(\mathrm{kg}) \times 0.8$ (Unakitan et al. 2010).

- Amount of tomato consumption $(\mathrm{kg}) \times 0.8$ (Unakitan et al. 2010).

\subsubsection{Study indicators}

Indicators are used as a tool to compare systems. Energy indicators also provide a detailed study of them. There are 4 important energy indicators that can comprehensively understand the energy situation in agriculture (Ghasemi-Mobtaker et al. 2012). After examining the different stages of the product, energy production and consumption in products can be calculated by different methods in different regions (Ali et al. 2017). The ratio between the 
calorific value of the output products and the total energy expended in the factors of production is called the energy ratio (Equation 2). This index lacks a unit and shows the effect of the input energy unit in achieving consumer goals. Consumer targets can be food, biomass or biofuels and products. This index is calculated using the information collected in this study (Canakci and Akinci 2006).

$$
\text { Energy use efficiency }=\frac{\text { Output energy }(\mathrm{MJ})}{\text { Input energy }(\mathrm{MJ})}
$$

Net energy efficiency or net energy produced is the difference between the gross energy produced and the total energy required for production. In the agricultural process, the NEG unit depends on the production unit. In this study, this index is measured in $\mathrm{MJ} \mathrm{ha}^{-1}$ (Equation 3) (Demircan et al. 2006).

Net energy $=$ Output energy (MJ) - Input energy (MJ)

Energy productivity index is the amount of product produced per unit of input energy (Equation 4). Energy productivity varies depending on the product, place and time. This index can be used as an indicator to evaluate the energy in the production system with a specific product. To improve productivity in a process, energy consumption in input generation can be reduced and product performance can be improved (Pishgar-Komleh et al. 2011).

Energy productivity $=\frac{\text { Production }(\mathrm{kg})}{\text { Input energy }(\mathrm{MJ})}$

Specific energy is the ratio of the total input energy to the amount of the output product and is determined in $\mathrm{MJ} \mathrm{kg}^{-1}$. In fact, this index is the opposite of energy productivity and expresses the energy consumed to produce each unit of product (Sartori et al. 2005). 


$$
\text { Specific energy }=\frac{\text { Input energy }(\mathrm{MJ})}{\text { Production }(\mathrm{kg})}
$$

\subsection{LCA analysis method}

Currently, environmental issues are the most important global issues in many countries. One of the topics of interest to the world community in recent years includes having sufficient information about the environmental status of countries and examining the trend of environmental change (Khanali et al. 2017). Among the various methods for the environmental study of processes and the production of crops and services, the use of life cycle assessment is required. The life cycle assessment method includes a set of systematic methods for collecting and evaluating materials, input and output energy, and environmental impacts associated with a production system over its life cycle (de Backer et al. 2009). The life cycle assessment process helps decision makers choose the product or process with the least environmental impact. Life cycle assessment also prevents the transmission of environmental problems from one stage to another (Coltro et al. 2006). In general, this method is divided into four parts: expressing the purpose and reference unit, determining the inputs and outputs of the system, assessing the environmental impacts and interpreting them (Martin-Gorriz et al. 2014). The following are four sections:

Step 1: The goal of the research must first be clear. In this study, the goal of this study is to investigate the environmental effects of greenhouse cucumber and tomato production by life cycle assessment method. The scope of evaluation of a life cycle should clearly define the function (system performance characteristics) being studied. The functional unit should be compatible with the purpose and scope of the study (Romero-Gámez et al. 2014). In fact, a functional unit is a quantitative description of the service system or product of the process under consideration. Three different functional units have been proposed for evaluating 
agricultural products based on unit area, currency unit and mass unit of production material (ISO 2006). In this study, the functional unit of one ton of cucumber and tomato produced in greenhouses of Tehran province was considered. The boundary of the system determines the processes that must be included in the life cycle assessment. The choice of system boundary should be consistent with the purpose of the study (de Backer et al. 2009). The criteria used to establish the system boundary must be identified and explained. The decision should be the same as the unit of processes included in the study. The details of the process unit must also be studied (Taherzadeh-Shalmaei et al. 2021). In this system, the boundaries of the study start from the preparation and entry of inputs into the greenhouse and end with the harvest of cucumbers and tomatoes (Figure 1).

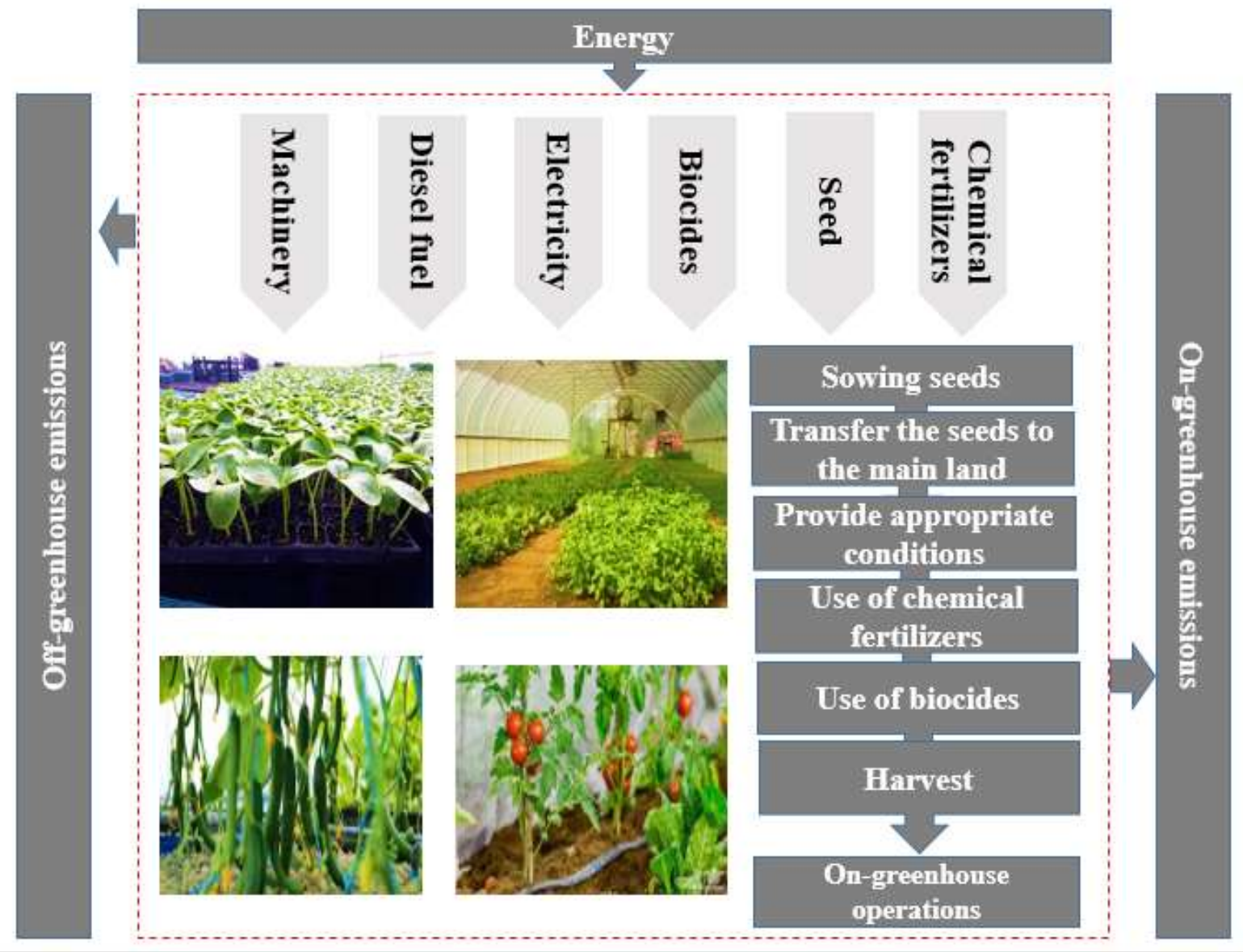

Fig. 1. Boundary of greenhouse cucumber and tomato system in Tehran province, Iran 
Step 2: In this section, all inputs are considered for production. All amounts of pollutants released into the environment are determined by the use of these inputs. These values are then calculated based on functional units (Paramesh et al. 2018). The quality of data collected for inventory analysis is a critical factor in the successful implementation of life cycle assessment. Achieving reliable data is an important factor in the development and use of life cycle assessment in environmental management (Cellura et al. 2012). The main result of this step is to provide a table of lists of inputs (materials and energy) and outputs (emissions to the environment) per functional unit. The calculated values are considered as input for the effect evaluation stage (Pirlo et al. 2014). Data from the EcoInvent database were used to calculate the rate of emission of indirect environmental pollutants (Off-greenhouse) due to the use of chemical fertilizers, diesel fuel, human labor and biocides produced. On the other hand, the standard equations provided by IPCC have been used to calculate the emission of pollutants due to the consumption of inputs (Edenhofer 2015). Table 3 shows the list analysis for each MJ of diesel fuel emissions. Emissions of the most important greenhouse gases, including carbon dioxide $\left(\mathrm{CO}_{2}\right)$, nitrous oxide $\left(\mathrm{N}_{2} \mathrm{O}\right)$ and methane $\left(\mathrm{CH}_{4}\right)$ from burning per liter of diesel were $74.5 \mathrm{~g}, 2.86 \mathrm{E}-03 \mathrm{~g}$ and $3.08 \mathrm{E}-03 \mathrm{~g}$, respectively. The emissions of $\mathrm{SO}_{2}$ and $\mathrm{NO}_{\mathrm{x}}$ pollutants were $2.41 \mathrm{E}-02 \mathrm{~g}$ and $1.06 \mathrm{~g}$ per liter of diesel, respectively. Coefficients for converting pollutants calculated by the above equations to their functional values are also presented in Table 4. The amount of emissions of each of the inputs to the weather is reported. The chemical fertilizers used contain heavy metals. Heavy metal contaminants enter the soil. The coefficients for calculating greenhouse gas emissions in the soil are given in Table 5.

Table 3

Equivalent on-greenhouse emission of $1 \mathrm{MJ}$ diesel fuel for $1 \mathrm{MJ}$ burning in EcoInvent database.

\begin{tabular}{ll}
\hline Emission & Amount $\left(\mathrm{g} \mathrm{MJ}^{-1}\right.$ diesel $)$ \\
\hline $\mathrm{CO}_{2}$ & 74.5 \\
$\mathrm{SO}_{2}$ & $2.41 \mathrm{E}-02$ \\
$\mathrm{CH}_{4}$ & $3.08 \mathrm{E}-03$
\end{tabular}




\begin{tabular}{ll} 
Benzene & $1.74 \mathrm{E}-04$ \\
$\mathrm{Cd}$ & $2.39 \mathrm{E}-07$ \\
$\mathrm{Cr}$ & $1.19 \mathrm{E}-06$ \\
$\mathrm{Cu}$ & $4.06 \mathrm{E}-05$ \\
$\mathrm{~N}_{2} \mathrm{O}$ & $2.86 \mathrm{E}-03$ \\
$\mathrm{Ni}$ & $1.67 \mathrm{E}-06$ \\
$\mathrm{Zn}$ & $2.39 \mathrm{E}-05$ \\
$\mathrm{Benzo}(\mathrm{a})$ pyrene & $7.16 \mathrm{E}-07$ \\
$\mathrm{NH}_{3}$ & $4.77 \mathrm{E}-04$ \\
$\mathrm{Se}$ & $2.39 \mathrm{E}-07$ \\
$\mathrm{PAH}$ & $7.85 \mathrm{E}-05$ \\
$\mathrm{HC}$, as NMVOC & $6.80 \mathrm{E}-02$ \\
$\mathrm{NO}$ & 1.06 \\
$\mathrm{CO}$ & $1.50 \mathrm{E}-01$ \\
Particulates $(\mathrm{b} 2.5 \mu \mathrm{m})$ & $1.07 \mathrm{E}-01$ \\
\hline
\end{tabular}

\section{Table 4}

Coefficients for calculating on-greenhouse emissions related to application of inputs in greenhouse cucumber and tomato production (IPCC 2006).

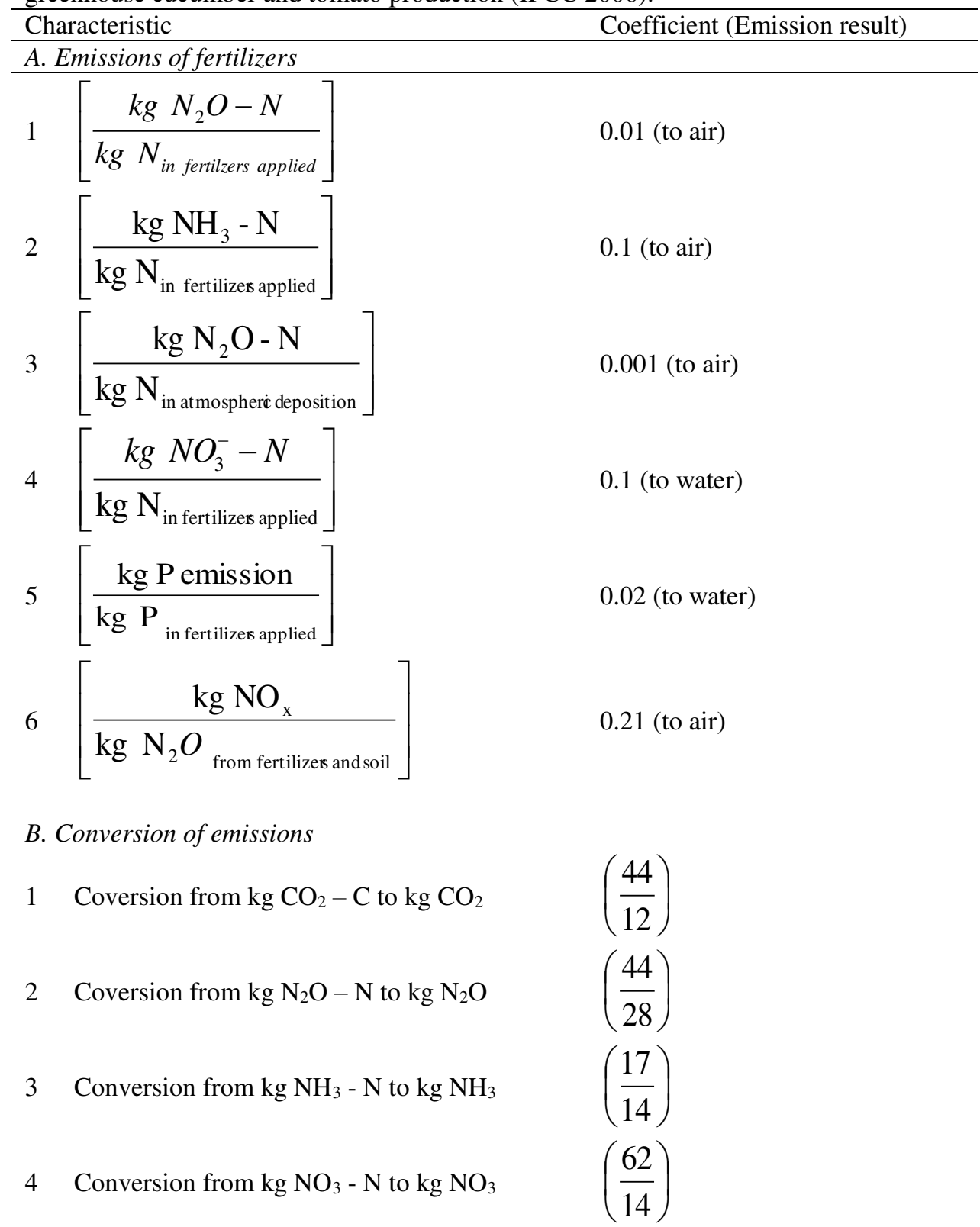


5 Conversion from $\mathrm{kg} \mathrm{P}_{2} \mathrm{O}_{5}$ to $\mathrm{kg} \mathrm{P} \quad\left(\frac{62}{164}\right)$

C. Emissions from human labor

$1\left[\frac{\mathrm{kg} \mathrm{CO}}{\text { man - h Human labor }}\right]$

0.7 (to air)

D. Emissions from biocides

$\begin{array}{lll}1 & {\left[\frac{\mathrm{kg} \text { effective material }}{\mathrm{kg} \text { biocides }}\right]} & 0.1 \text { (to air) } \\ 2\left[\frac{\mathrm{kg} \text { effective material }}{\mathrm{kg} \text { biocides }}\right] & 0.85 \text { (to soil) }\end{array}$

Table 5

Coefficients for calculating on-greenhouse emissions to soil of heavy metal related to application of chemical fertilizers in greenhouse cucumber and tomato production (IPCC 2006).

\section{Characteristic}

$1\left[\frac{\mathrm{mg} \text { Heavy metal }}{k g N_{\text {in fertilzer applied }}}\right]$

$2\left[\frac{\text { mg Heavy metal }}{k g P_{2} O_{5} \text { in fertizer applied }}\right]$

$3\left[\frac{\mathrm{mg} \text { Heavy metal }}{\mathrm{kg} \mathrm{K}_{2} \mathrm{O}_{\text {in fertizer applied }}}\right]$

$4\left[\frac{\mathrm{mg} \text { Heavy metal }}{k g \text { Dry material of cow manure }{ }_{\text {in fertizer applied }}}\right]$

\section{Heavy metals}

$\mathrm{Cd} \quad \mathrm{Cu}$

6

26

Zn

$\mathrm{Pb}$

$\mathrm{Ni}$

$\mathrm{Cr}$ $\mathrm{Hg}$

203

5409

20.9

77.9

39.5

$90.5 \quad 839$

67

88.3

543

0.1

4.8

6.2

0.8

$2.5 \quad 5.8$

0

452.3

1018

13.6

17.4

13.2

0.08

452.2

Step 3: The purpose of this step is to quantitatively analyze the results of the life cycle audit section. Life cycle impact assessment is divided into three sub-categories: classification, normalization, and weighting (Martin-Gorriz et al. 2014). In the life cycle impact assessment phase, the set of results of the previous phase is interpreted based on environmental impacts. At the end of this step, a list of effect groups is defined and modeled for environmental 
interventions related to the appropriate indicators of the effect groups (Mouron et al. 2006). In the classification stage, the coefficient or weight of each pollutant is applied to different impact groups. In other words, by multiplying the factor of pollutants in the form of different impact groups in the amount of pollutants consumption, the classification index of each impact group was calculated (Antón et al. 2014). In this study, the environmental impact assessment method was performed based on the ReCiPe2016 model. This model has been used in extensive research in the field of agricultural production. Accordingly, the endpoint area of human health is defined by the categories increase in respiratory disease, increase in various types of cancer, increase in other diseases/causes and increase in malnutrition. The endpoint area of ecosystem damage was examined with three subgroups damage to freshwater species, damage to terrestrial species and damage to marine species. Resource damage category includes increased extraction costs (Mostashari-Rad et al. 2019).

Step 4: All steps ultimately lead to the interpretation of the results. The final indicators were classified into three groups: damage to human health, damage to ecosystems and damage to resource availability. The purpose of interpreting the results is to determine the limitations, recommendations, and findings of the life cycle impact assessment phase to assist decision makers. As a result, decisions about environmental pollutants are improved (Ruviaro et al. 2012).

\subsection{CExD analysis method}

Exergy helps analyze energy and other systems and processes (Bösch et al. 2007). Exergy makes better use of the environmental benefits and economics of energy technologies. Exergy analysis has been used to analyze the use of energy in a country to better understand the efficiency of energy use. Exergy the system is the most useful work possible during a process that balances the system with the environment (Nabavi-Pelesaraei et al. 2016). Cumulative exergy index is expressed as the total exergy of all resources for production. The 
quality of energy sources as well as non-energy sources is also examined (Hischier et al. 2015). This method includes 7 indices of renewable energy and non-renewable energy effect categories, the sum of which was considered as cumulative exergy demand (Figure 2).

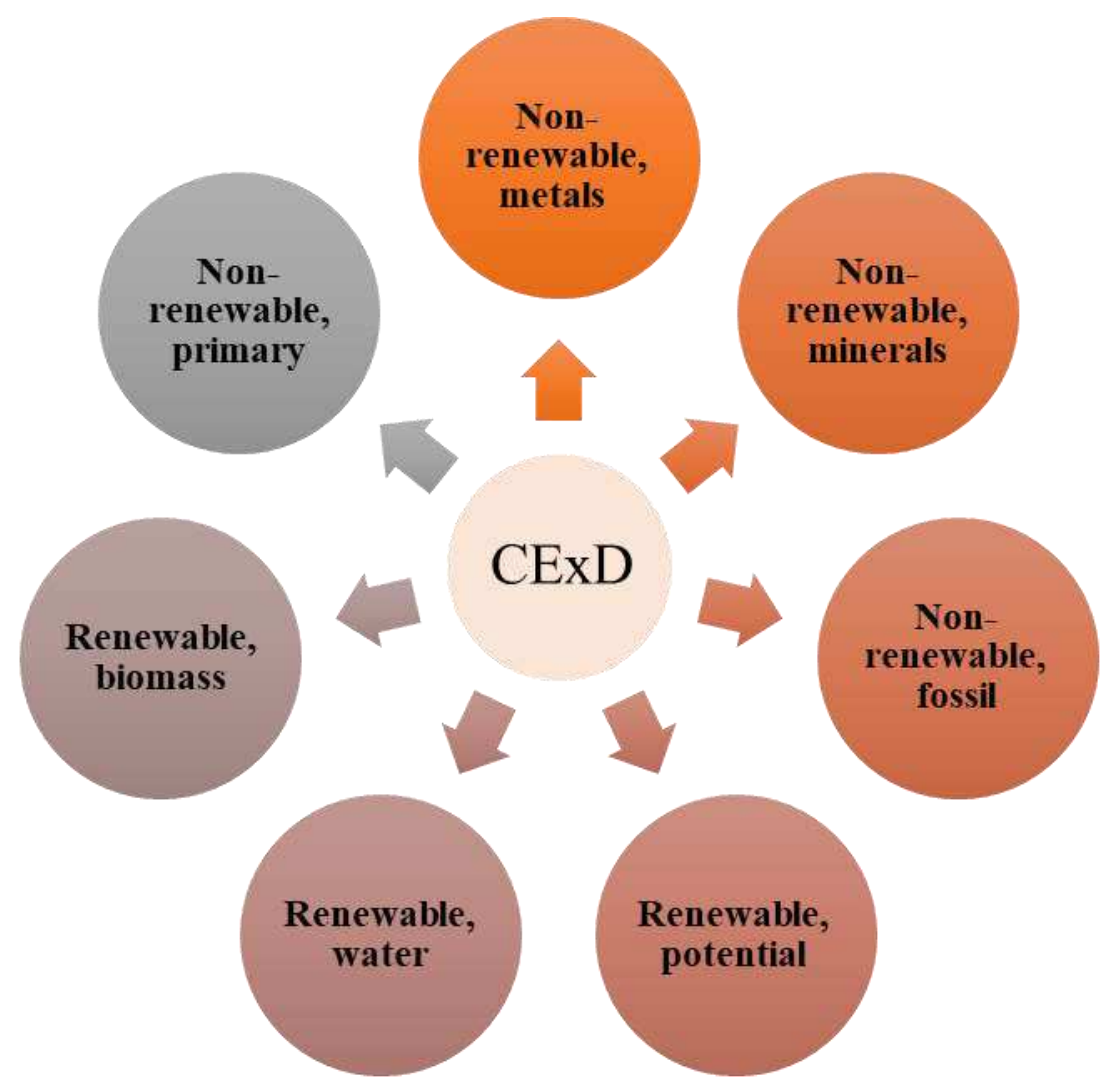

Fig. 2. Configurations of CExD components to evaluate energy forms in greenhouse cucumber and tomato production.

\section{Results and discussion}

\subsection{Comparison of cucumber and tomato energy analysis}

Energy analysis is reported in Table 6. According to the calculations made in this section, a comparison of greenhouse cucumber and greenhouse tomato has been done. The energy consumption of tomato is $7506.24 \mathrm{MJ}$ more than the energy consumption of cucumber per hectare. Yield of cucumber and tomato per hectare is $131228.67 \mathrm{~kg}$ and $285351.70 \mathrm{~kg}$, 
respectively. The amount of energy produced by tomato is $123298.43 \mathrm{MJ}$ per hectare more than the energy produced by cucumbers. Each of the inputs used for production in the greenhouse has a different share. The share of energy consumption of each of the inputs is shown in Figures 3 and 4 for cucumbers and tomatoes, respectively. Diesel fuel with more than 250,000 MJ per hectare has the highest energy consumption among inputs. In greenhouse cucumbers (Khoshnevisan et al. 2013) and strawberries (Khoshnevisan et al. 2014a), fuel consumption had the largest share in energy consumption. This result shows that in Iranian greenhouses, the main energy consumption is related to greenhouse heating. Diesel fuel, electricity, nitrogen and human labor have the largest share of energy with about 60, 12, 11 and $8 \%$, respectively. Consumed seeds also have the least amount of energy for cucumber (0.10 MJ per ha) and tomato (0.08 MJ per ha). The results of studying the energy consumption pattern of greenhouse tomato showed that the highest amount of energy consumed includes chemical fertilizers (38.2\%) and electricity (27.09\%). The average yield and energy consumption are $57905.1 \mathrm{~kg} \mathrm{ha}^{-1}$ and 61434.5 $\mathrm{MJ} \mathrm{ha}^{-1}$, respectively (Ozkan et al. 2011). The results of greenhouse cucumber energy showed that fuel institution with $47 \%$ had the highest and water consumption with $1.2 \%$ had the lowest share of energy consumption in greenhouses (Taki et al. 2013). Figure 5 shows a comparison of energy consumption between different inputs in two products. There is no difference in the energy consumption of biocides, electricity, diesel fuel and human labor of two products. Phosphate and seed energy consumption are the most different between cucumber and tomato products.

Table 6

Amounts of inputs-outputs energy in greenhouse cucumber and tomato production of Tehran province.

\begin{tabular}{|c|c|c|c|c|}
\hline \multirow{3}{*}{ Items } & \multicolumn{4}{|c|}{ Greenhouse crops } \\
\hline & \multicolumn{2}{|l|}{ Cucumber } & \multicolumn{2}{|l|}{ Tomato } \\
\hline & Unit per ha & Energy use $\left(\mathrm{MJ} \mathrm{ha}^{-1}\right)$ & Unit per ha & Energy use $\left(\mathrm{MJ} \mathrm{ha}^{-1}\right)$ \\
\hline \multicolumn{5}{|l|}{ A. Inputs (unit) } \\
\hline 1. Human labor (h) & 16955.82 & 33233.41 & 17532.30 & 34363.31 \\
\hline 2. Agricultural machinery $(\mathrm{kg})$ & 9.48 & 1352.80 & 9.12 & 1301.42 \\
\hline 3. Diesel fuel (L) & 4490.20 & 252843.16 & 4540.78 & 255691.32 \\
\hline \multicolumn{5}{|l|}{ 4. Chemical fertilizers $(\mathrm{kg})$} \\
\hline (a) Nitrogen & 701.70 & 46410.44 & 677.69 & 44822.42 \\
\hline (b) Phosphate $\left(\mathrm{P}_{2} \mathrm{O}_{5}\right)$ & 797.69 & 9923.26 & 675.23 & 8399.86 \\
\hline
\end{tabular}


(c) Potassium (K)

5. Biocides $(\mathrm{kg})$

7. Electricity (kwh)

8. Cucumber seed

9. Tomato seed

Total energy use (MJ)

B. Output $(\mathrm{kg})$

1. Cucumber

2. Tomato

$\begin{array}{ll}811.91 & 9052.80 \\ 33.48 & 4017.60 \\ 4047.68 & 48572.16 \\ 0.13 & 0.10 \\ - & - \\ - & \mathbf{4 0 5 4 0 5 . 7 5}\end{array}$

$131228.67 \quad 104982.94$

$\begin{array}{ll}767.54 & 8558.07 \\ 38.81 & 4657.20 \\ 4593.19 & 55118.28 \\ - & - \\ 0.11 & 0.08 \\ - & \mathbf{4 1 2 9 1 1 . 9 9} \\ & \\ - & - \\ 285351.70 & 228281.37\end{array}$

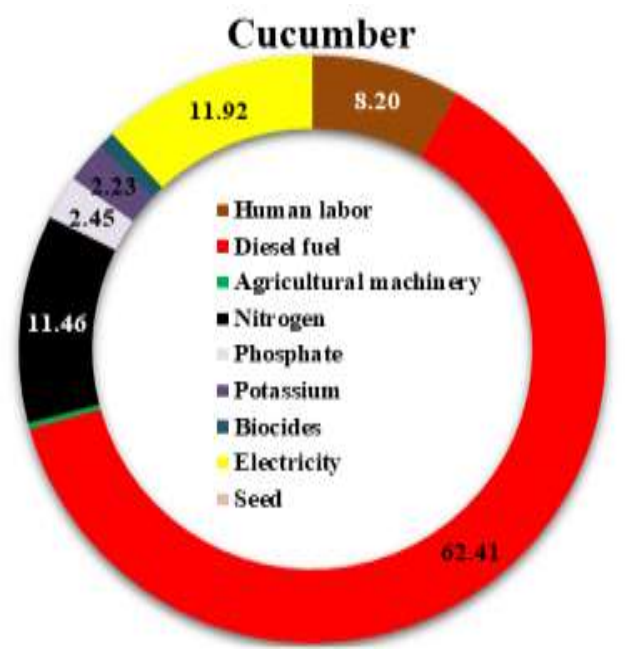

Fig. 3. Shares of energy sources in cucumber production.

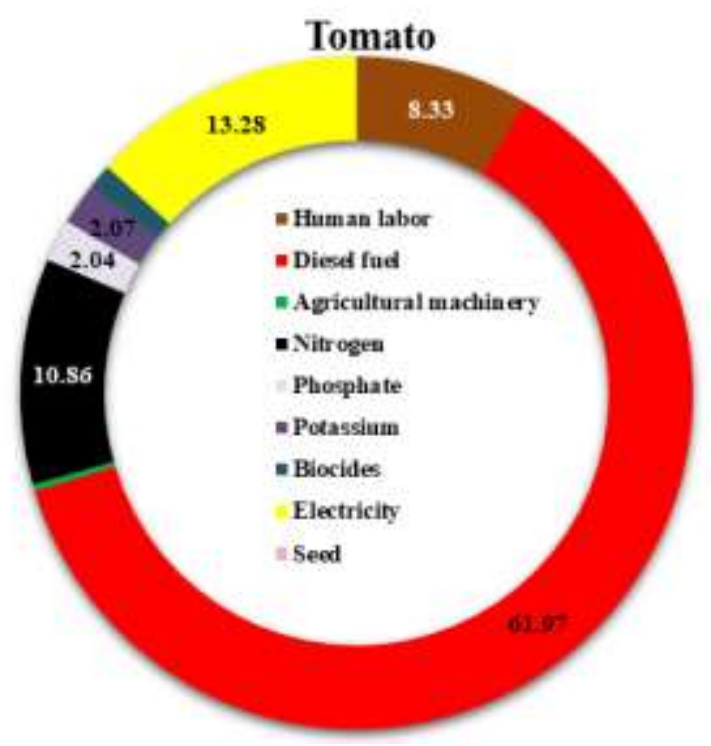

Fig. 4. Shares of energy sources in tomato production. 


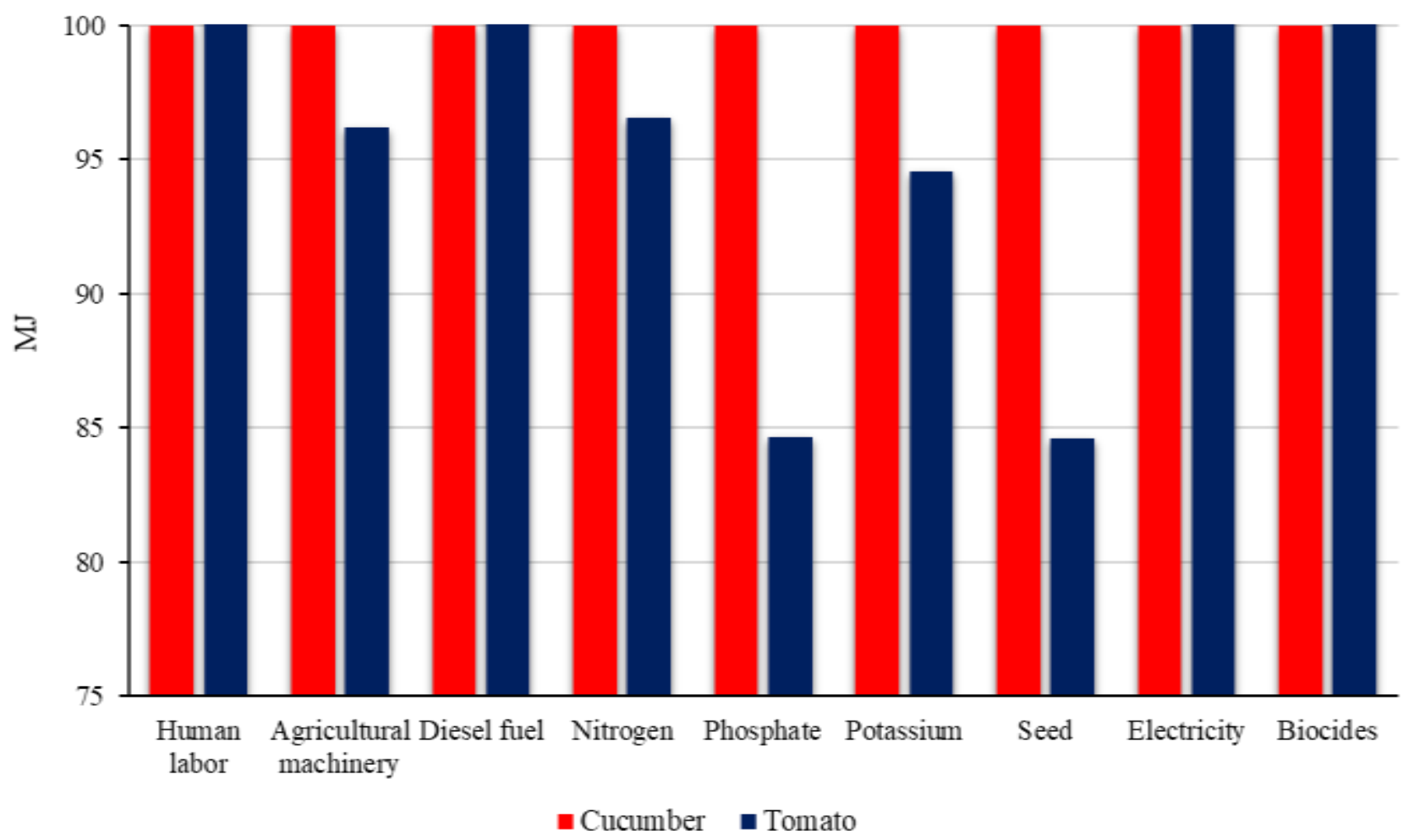

Fig. 5. Comparison between energy inputs in cucumber and tomato production.

\subsection{Indicators report}

In another part of the energy analysis, the indicators were examined (Table 7). The energy ratio of cucumber and tomato was less than one. This result shows that the amount of output energy is less than the sum of input energies. The ratio of output energy to input energy of tomato (0.55) is higher than cucumber (0.26). Hatirli et al. (2006b) reported that the energy ratio in tomato production was 1.21 . Therefore, it can be concluded that the energy consumption performance in Tehran province, Iran is lower than the energy consumption performance in the production of this product in Turkish greenhouses. The energy ratio index in greenhouse production of vegetables such as cucumber, tomato, pepper and eggplant was calculated to be $0.31,0.32,0.23$ and 0.19 , respectively (Canakci and Akinci 2006). Energy ratio index in Iran for cucumber greenhouse production was equal to 0.12 (Khoshnevisan et al. 2013) and in strawberry greenhouse production was calculated 0.12 (Khoshnevisan et al. 2014b). Tomato $\left(0.69 \mathrm{~kg} \mathrm{MJ}^{-1}\right)$ is also more energy productivity than cucumber $(0.32 \mathrm{~kg}$ 
$\mathrm{MJ}^{-1}$ ). In terms of energy consumption of inputs, tomato have more performance. The energy intensity of cucumber is $3.09 \mathrm{MJ} \mathrm{kg}^{-1}$. The energy intensity of tomato in this study was higher than the energy intensity reported in Canakci and Akinci, (2006) research (0.4 MJ $\mathrm{kg}^{-1}$ ). In the study on cucumber, the energy ratio was calculated to be 0.1 . The calculations showed that the total cucumber energy of input and output were $1284000 \mathrm{MJ} \mathrm{ha}^{-1}$ and 12500 MJ ha ${ }^{-1}$, respectively (Pishgar-Komleh et al. 2013). The net energy gains of cucumber (300139.13 $\left.\mathrm{MJ} \mathrm{ha}^{-1}\right)$ and tomato $\left(-184308.90 \mathrm{MJ} \mathrm{ha}^{-1}\right)$ was calculated negatively. In the Mohammadi and Omid (2010) report, more input energy was reported than output energy (53027.16 $\left.\mathrm{MJ} \mathrm{ha}^{-1}\right)$.

Table 7

Energy indices in greenhouse cucumber and tomato production.

\begin{tabular}{lll}
\hline Items & \multicolumn{2}{c}{ Greenhouse crops } \\
\cline { 2 - 3 } & Cucumber & Tomato \\
\hline Energy use efficiency (ratio) & 0.26 & 0.55 \\
Energy productivity $\left(\mathrm{kg} \mathrm{MJ}^{-1}\right)$ & 0.32 & 0.69 \\
Specific energy $\left(\mathrm{MJ} \mathrm{kg}^{-1}\right)$ & 3.09 & 1.45 \\
Net energy gain $\left(\mathrm{MJ} \mathrm{ha}^{-1}\right)$ & -300139.13 & -184308.90
\end{tabular}

\subsection{ReCiPe method analysis}

The On-greenhouse emissions of inputs into air, water and soil is reported in Table 8. Diesel fuel into the air has various pollutants. Carbon dioxide has the highest content among 18 air pollutants. Cucumber carbon dioxide $18498.53 \mathrm{~kg}$ has more emissions than tomato. The amount of $\mathrm{NH}_{3}$ released into the air is due to the use of chemical fertilizers. $\mathrm{NH}_{3}$ emissions for cucumber $(85.20 \mathrm{~kg})$ and tomato $(82.29 \mathrm{~kg})$ are not much different. The amount of emissions caused by chemical fertilizers and heavy metals due to it in cucumber production is more than tomato. Although the use of pesticides and chemical fertilizers in the production of greenhouse crops increases the yield and improves the quality of crops, but it has destructive effects. Pollution of the environment, accumulation of pollutants such as nitrate in the organs of agricultural products and endangering the health of humans and animals are examples of the harmful effects of excessive use of chemical fertilizers (Xue et al. 2015). The results of 
analysis of field tomato emissions showed that due to seasonal changes, the amount of pollution varies from 16183 to $22426 \mathrm{~kg}$ of equivalent carbon dioxide per hectare. Irrigation and nitrogen fertilizer also had the highest levels of pollution among inputs (Jones et al. 2012). Cucumber research from (Pishgar-Komleh et al. 2013) also shows that diesel, with more than $60 \%$, has a large share in greenhouse gas emissions $(82,724 \mathrm{~kg} \mathrm{CO} 2 \mathrm{eq})$. Carbon dioxide from human labor activities for cucumber $(11869.07 \mathrm{~kg})$ is less than tomato $(12272.61 \mathrm{~kg})$. Biocides are also released into the air and soil.

Table 8

On-greenhouse emissions of cucumber and tomato production in Tehran province of Iran based on 1 hectare.

\begin{tabular}{|c|c|c|}
\hline \multirow{2}{*}{ Item (unit) } & \multicolumn{2}{|c|}{ Greenhouse crops } \\
\hline & Cucumber & Tomato \\
\hline \multicolumn{3}{|l|}{ 1. Emissions by diesel fuel to air $(\mathrm{kg})$} \\
\hline (a). $\mathrm{CO}_{2}$ & 18836.81 & 338.28 \\
\hline (b). $\mathrm{SO}_{2}$ & 6.09 & 0.10 \\
\hline (c). $\mathrm{CH}_{4}$ & 0.77 & 0.01 \\
\hline (d). Benzene & 0.04 & 0.00079 \\
\hline (e). $\mathrm{Cd}$ & $6.04 \mathrm{E}-05$ & $1.08 \mathrm{E}-06$ \\
\hline (f). $\mathrm{Cr}$ & 0.0003 & $5.40 \mathrm{E}-06$ \\
\hline (g). $\mathrm{Cu}$ & 0.01 & 0.0001 \\
\hline (h). $\mathrm{N}_{2} \mathrm{O}$ & 0.72 & 0.01 \\
\hline (i). $\mathrm{Ni}$ & 0.0004 & $7.58 \mathrm{E}-06$ \\
\hline (j). $\mathrm{Zn}$ & 0.006 & 0.0001 \\
\hline (k). Benzo (a) pyrene & 0.0001 & $3.25 \mathrm{E}-06$ \\
\hline (1). $\mathrm{NH}_{3}$ & 0.12 & 0.002 \\
\hline (m). Se & $6.04 \mathrm{E}-05$ & $1.08 \mathrm{E}-06$ \\
\hline (n). PAH & 0.019 & 0.0003 \\
\hline (o). HC, as NMVOC & 17.19 & 0.30 \\
\hline (p). $\mathrm{NO}_{\mathrm{x}}$ & 268.01 & 4.81 \\
\hline (q). $\mathrm{CO}$ & 37.92 & 0.68 \\
\hline (r). Particulates (b2.5 $\mu \mathrm{m})$ & 27.05 & 0.48 \\
\hline \multicolumn{3}{|l|}{ 2. Emissions by fertilizers to air $(\mathrm{kg})$} \\
\hline (a). $\mathrm{NH}_{3}$ by chemical fertilizers & 85.20 & 82.29 \\
\hline \multicolumn{3}{|l|}{ 3. Emissions by fertilizers to water $(\mathrm{kg})$} \\
\hline (a). Nitrate & 93.22 & 90.03 \\
\hline (b). Phosphate & 17.41 & 14.74 \\
\hline \multicolumn{3}{|c|}{ 5. Emission by $\mathrm{N}_{2} \mathrm{O}$ of fertilizers to air $(\mathrm{kg})$} \\
\hline (a). NOx & 147.35 & 142.31 \\
\hline \multicolumn{3}{|l|}{ 6. Emission by human labor to air $(\mathrm{kg})$} \\
\hline (a). $\mathrm{CO}_{2}$ & 11869.07 & 12272.61 \\
\hline \multicolumn{3}{|c|}{ 7. Emission by heavy metals of fertilizers to soil (mg) } \\
\hline (a). $\mathrm{Cd}$ & 76563.52 & 65327.96 \\
\hline (b). $\mathrm{Cu}$ & 190429.64 & 164070.14 \\
\hline (c). $\mathrm{Zn}$ & 1685577.55 & 1444711.56 \\
\hline (d). $\mathrm{Pb}$ & 3919557.42 & 3770761.94 \\
\hline (e). $\mathrm{Ni}$ & 179452.50 & 154014.11 \\
\hline (f). $\mathrm{Cr}$ & 1056311.53 & 901512.57 \\
\hline (f). $\mathrm{Hg}$ & 709.74 & 617.18 \\
\hline \multicolumn{3}{|l|}{ 8. Emissions by biocides to air $(\mathrm{kg})$} \\
\hline (a). Benomyl & 0.04 & 0.32 \\
\hline
\end{tabular}


$\begin{array}{lll}\text { (b). Captan } & 0.06 & 0.45\end{array}$

(c). Thiophanate-methyl $\quad 0.01 \quad 0.86$

$\begin{array}{lll}\text { (d). Chlorothalonil } & 0.09 & 0.42\end{array}$

$\begin{array}{lll}\text { (e). Thiram } & 0.15 & 0.31\end{array}$

$\begin{array}{lll}\text { (f). Chloropicrin } & 0.06 & 0.44\end{array}$

(g). Parathion $\quad 0.13 \quad 0.52$

$\begin{array}{lll}\text { (h). Carbofuran } & 0.08 & 0.36\end{array}$

9. Emissions by biocides to soil $(\mathrm{kg})$
(a). Benomyl
$0.98 \quad 0.30$
(b). Captan
$0.41 \quad 0.81$
(c). Thiophanate-methyl
$0.52 \quad 0.47$
(d). Chlorothalonil
$\begin{array}{ll}0.31 & 0.69\end{array}$
(e). Thiram
$0.77 \quad 0.71$
(f). Chloropicrin
$0.42 \quad 0.53$
(g). Parathion
$0.99 \quad 0.10$
(h). Carbofuran
0.61 0.66

The amount of publications of the ReCiPe method classifications is shown in Table 9. The human health category has more releases for cucumber $\left(0.012\right.$ DALY $\left.^{a}\right)$ than for tomato $(0.004$ DALY $^{a}$ ). Resource releases are more relevant than the other two categories. Resources have significant amount for cucumber (25.35 USD2013). Ecosystem emissions are the lowest. Other studies on greenhouse production of cucumber and tomato have shown that the Freshwater Ecotoxicity potential index has the highest level of pollution (Khoshnevisan et al. 2014a). Similar results have been obtained for the production of greenhouse strawberry (Khoshnevisan et al. 2013). Each of the inputs used has different emissions for the three model ReCiPe categories. The share of each input is shown in Figure 6. The publications of the two products are compared in Figure 7. On-greenhouse emissions have the greatest impact on human health classification with $82 \%$ for cucumber and $78 \%$ for tomato. Ongreenhouse emissions also affect ecosystem classification with $78 \%$ for cucumber and $67 \%$ for tomato. Diesel fuel consumption emits $65 \%$ of pollutant resources. Electricity and nitrogen consumption also led to the release of pollutants related to the resources class. Electricity and nitrogen consumption have a greater impact on tomato and cucumber emissions, respectively. As a result, greenhouse cucumber has more emissions than tomato in different classes. Ali et al. (2017) reported that different cucumber farms have publications $16.90 \mathrm{~kg} \mathrm{CO} 2$ eq., $18.58 \mathrm{~kg} \mathrm{CO} 2$ eq. and $19.63 \mathrm{~kg} \mathrm{CO} 2$ eq. Diesel fuel, fertilizer, machinery, 
and chemicals had the largest share in cucumber emissions. The results of the LCA report showed that categories the respiratory inorganics, terrestrial acid/nutria, and aquatic acidification had a significant share in the publications. The human health category for arecanut production also had the highest value (Paramesh et al. 2018).

Table 9

Values of the environmental impact per one ton of cucumber and tomato production in Tehran province of Iran.

\begin{tabular}{llll}
\hline \multirow{2}{*}{ Impact categories } & \multirow{2}{*}{ Unit } & \multicolumn{2}{c}{ Greenhouse crops } \\
\cline { 3 - 4 } & & Cucumber & Tomato \\
\hline Human health & DALY ${ }^{\mathrm{a}}$ & 0.012 & 0.004 \\
Ecosystems & species.yr $^{\mathrm{b}}$ & $1.39 \mathrm{E}-05$ & $4.33 \mathrm{E}-06$ \\
Resources & USD2013 & 25.35 & 11.80 \\
\hline
\end{tabular}

a DALY: disability adjusted life years. A damage of 1 is equal to:
loss of 1 life year of 1 individual, or 1 person suffers 4 years from a
disability with a weight of 0.25 .
b species.yr: the unit for ecosystems is the local species loss
integrated over time.
integrated over time.

\section{Cucumber}

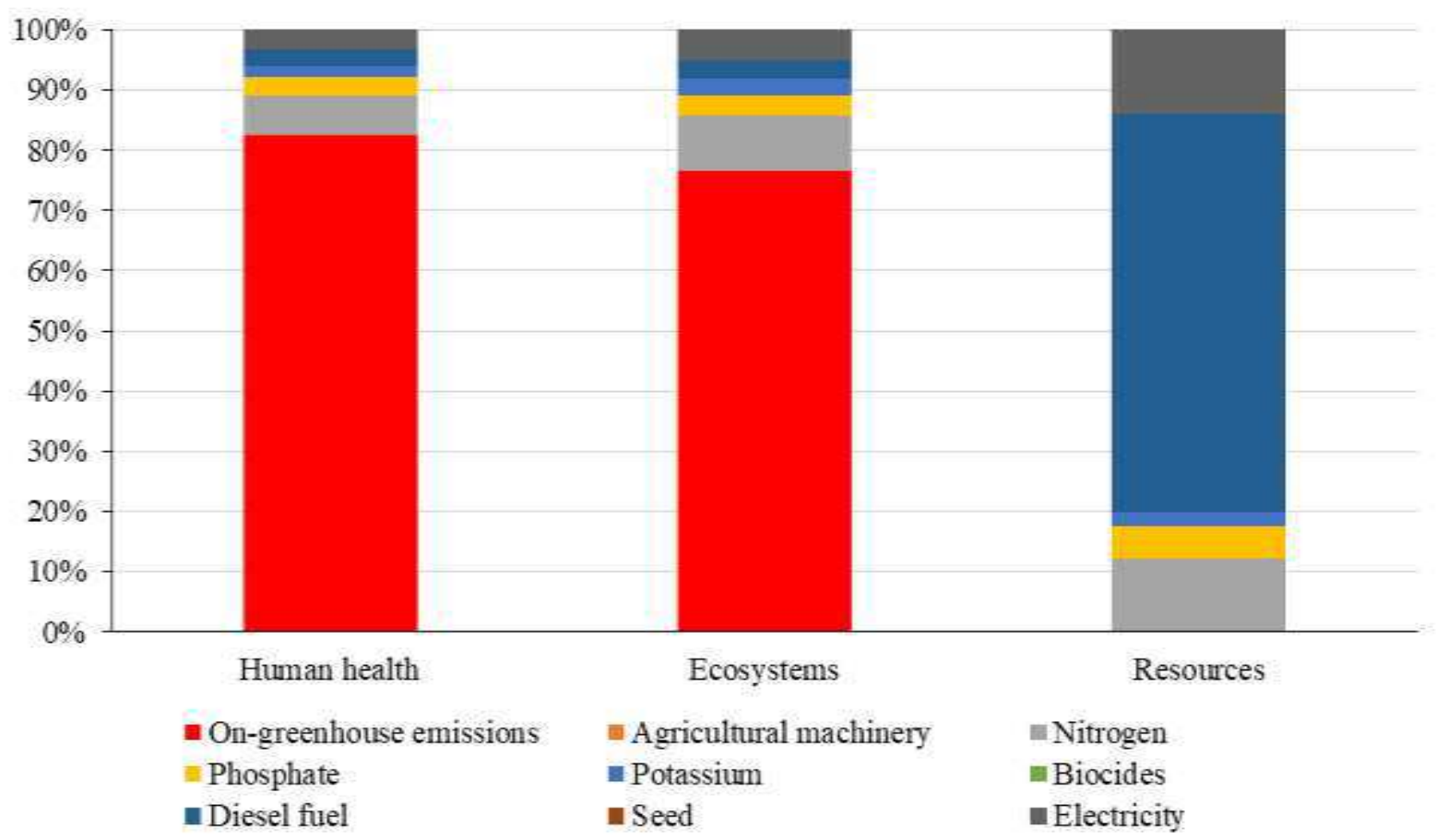




\section{Tomato}

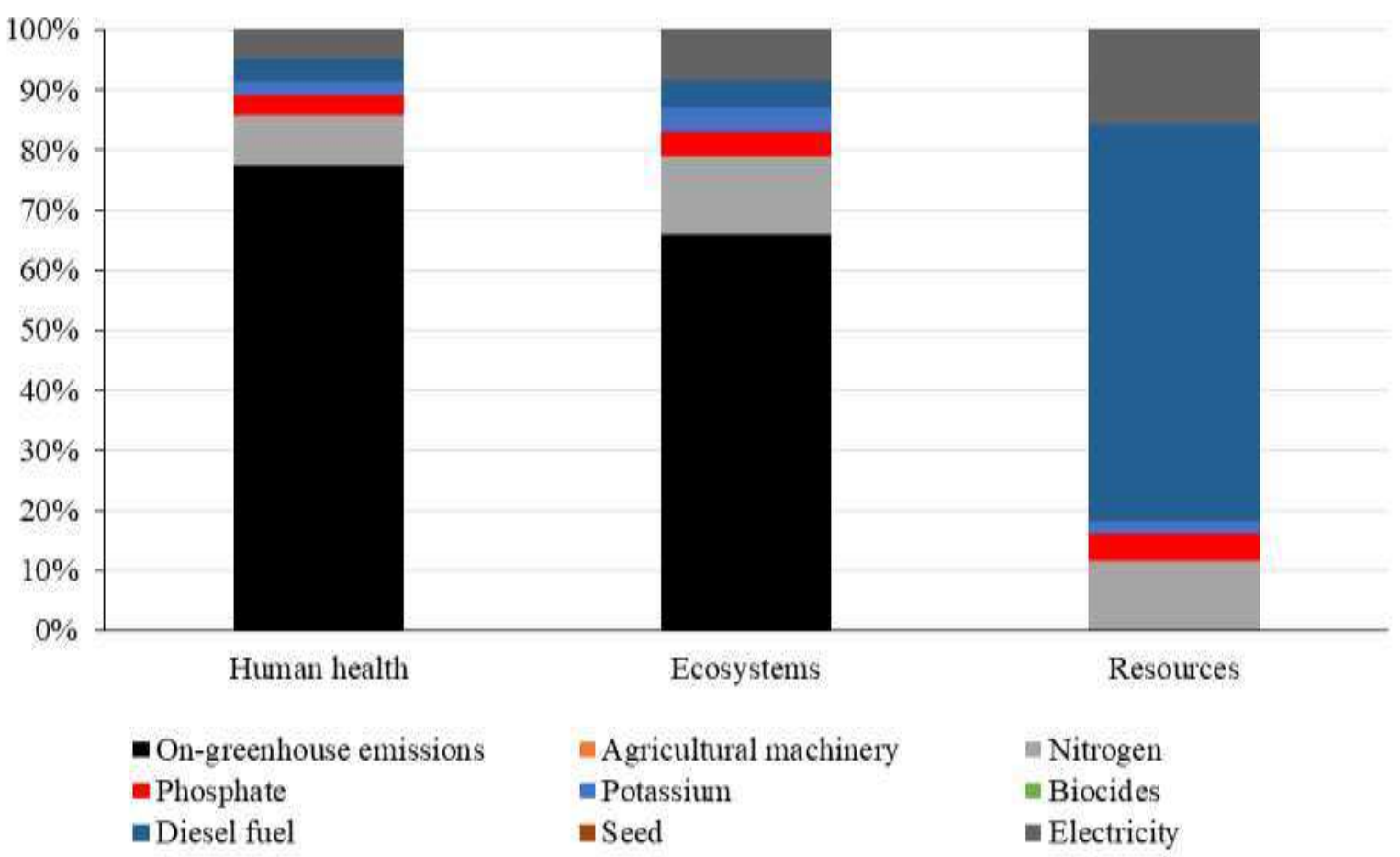

Fig. 6. Contribution of inputs to emit environmental impact categories of cucumber and tomato production

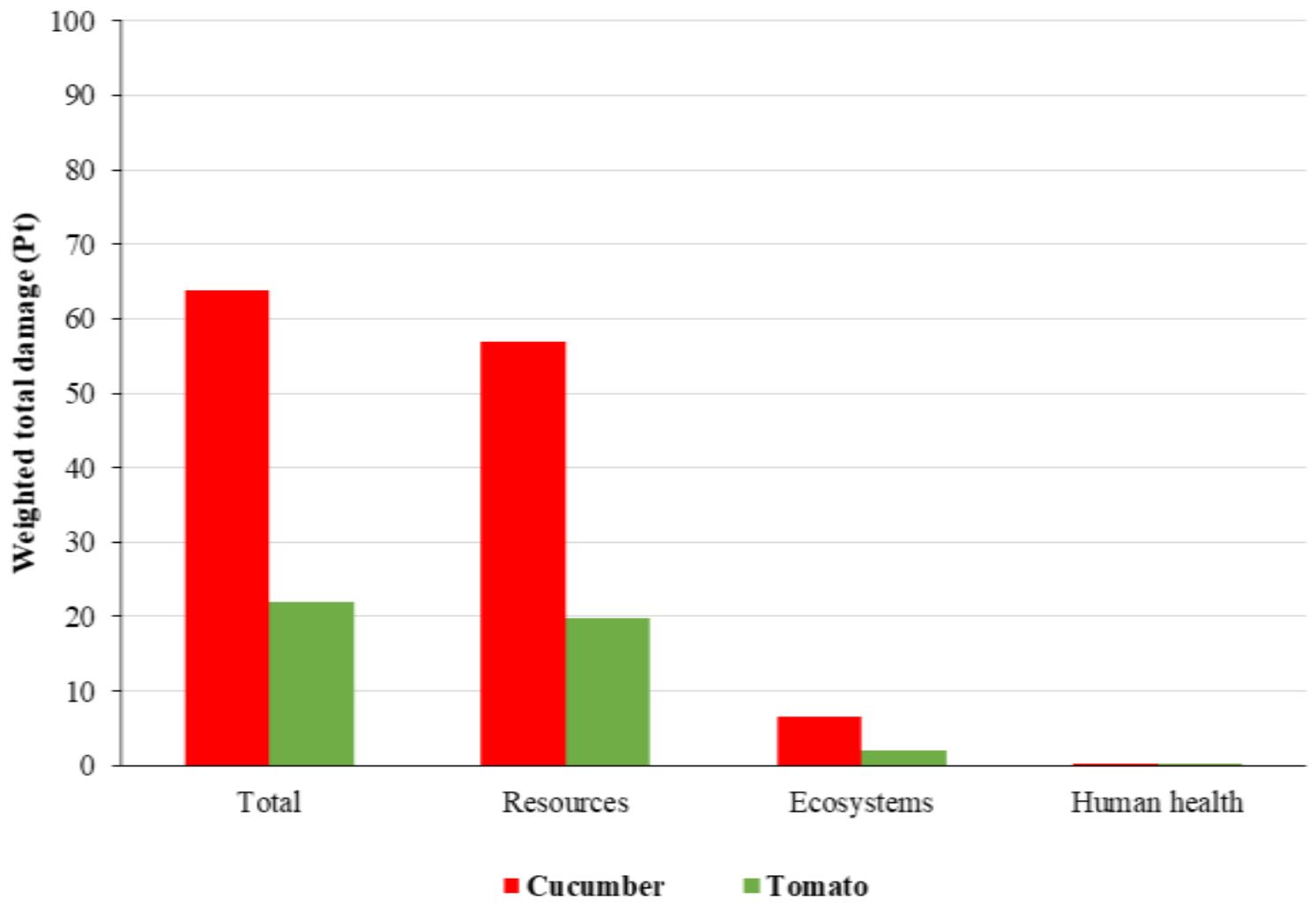


Fig. 7. Comparison between weighted environmental impacts of cucumber and tomato production.

\subsection{CExD method analysis}

The results of method CExD are shown in Table 10. Different values are obtained for energy forms. All forms of renewable and non-renewable energy for cucumber are greater than tomato. Non-renewable, fossil form has the highest energy produced for cucumber $(2802.88$ MJ ton ${ }^{-1}$ ) and tomato (1301.14 $\mathrm{MJ}^{-1}{ }^{-1}$ ). Renewable, biomass and Renewable, water forms are in the second and third ranks. Non-renewable, primary form had the lowest energy for cucumber (18.70 MJ ton ${ }^{-1}$ ) and tomato $\left(8.12 \mathrm{MJ} \mathrm{ton}^{-1}\right)$. The CExD analysis for conventional, low external input and organic systems of rice paddy production showed that Non- renewable, fossil fuel was the basic energy form (Saber et al. 2020). The CExD index for saffron was calculated as $1894.23 \mathrm{MJ} \mathrm{ha}^{-1}$ equivalent. This report shows that saffron has much less energy than cucumber and tomato (Khanali et al. 2017). To compare the energy forms of the two products according to the inputs used in the greenhouse, Figures 8 and 9 are presented. Chemical fertilizers and diesel fuel had the greatest impact on energy forms. Diesel fuel and electricity play an important role in the production of Non-renewable, fossil form with $60 \%$ and $15 \%$, respectively. Phosphate, nitrogen and potassium have the greatest effect on Nonrenewable, minerals form, Non-renewable, metals form and Non-renewable, primary form, respectively. Electricity (about 28\%) also has the largest share in the Renewable, potential form. In Zarei et al. (2019) study, diesel fuel and natural gas combustion had a significant contribution in CExD method analysis of cucumber and tomato. 
Table 10

The energy forms results of CExD analysis for one ton of cucumber and tomato production in Tehran province of Iran.

\begin{tabular}{llll}
\hline \multirow{2}{*}{ Energy form } & Unit & \multicolumn{2}{c}{ Greenhouse crops } \\
\cline { 3 - 4 } & & Cucumber & Tomato \\
\hline Non-renewable, fossil & MJ ton $^{-1}$ & 2802.88 & 1301.14 \\
Renewable, potential & MJ ton $^{-1}$ & 31.77 & 14.37 \\
Non-renewable, primary & $\mathrm{MJ} \mathrm{ton}^{-1}$ & 18.70 & 8.12 \\
Renewable, biomass & $\mathrm{MJ} \mathrm{ton}^{-1}$ & 246.67 & 107.09 \\
Renewable, water & $\mathrm{MJ} \mathrm{ton}^{-1}$ & 105.87 & 45.98 \\
Non-renewable, metals & $\mathrm{MJ} \mathrm{ton}^{-1}$ & 33.55 & 14.53 \\
Non-renewable, minerals & $\mathrm{MJ} \mathrm{ton}^{-1}$ & 53.81 & 21.69 \\
\hline
\end{tabular}

\section{Cucumber}

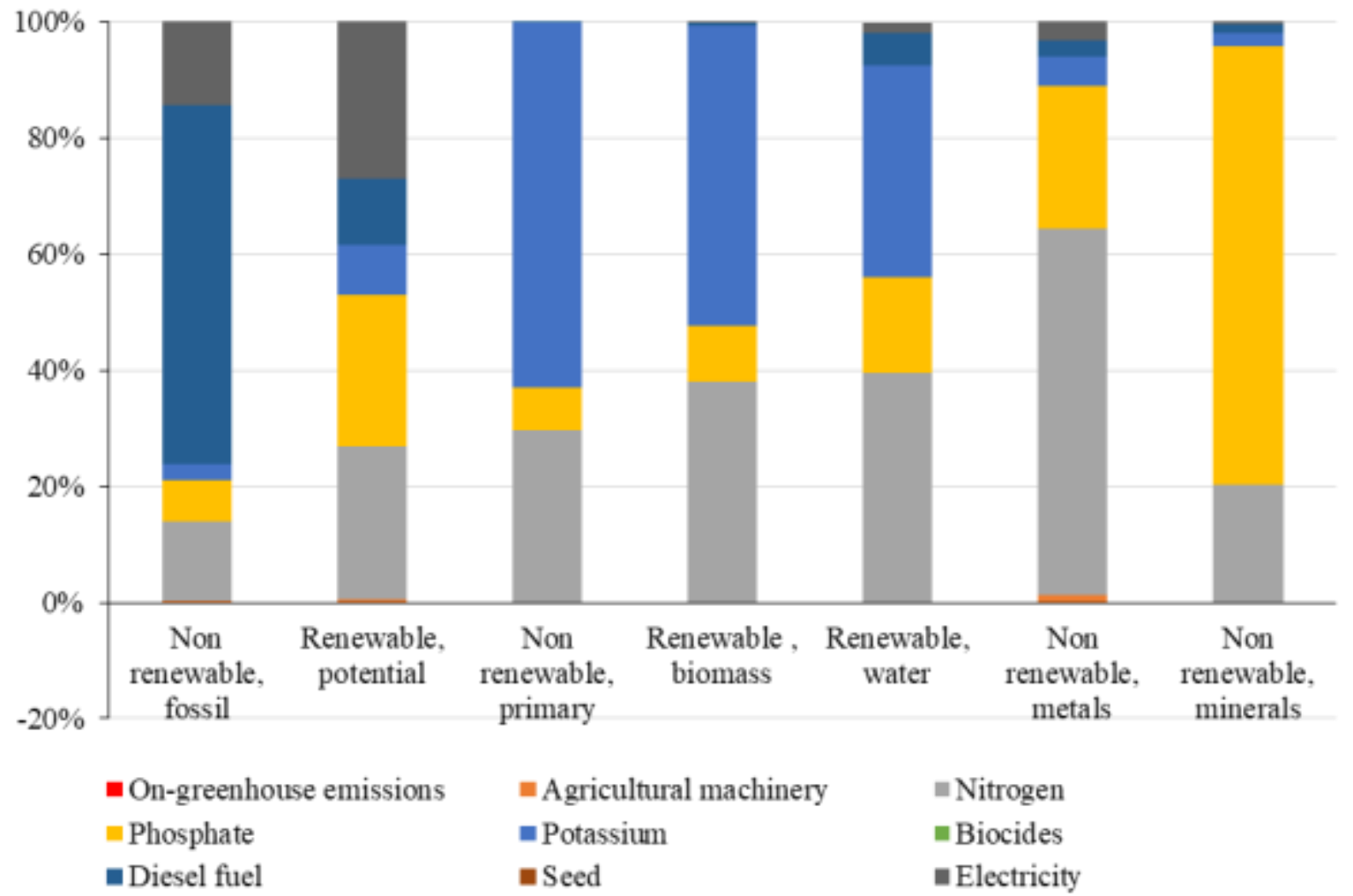


Tomato

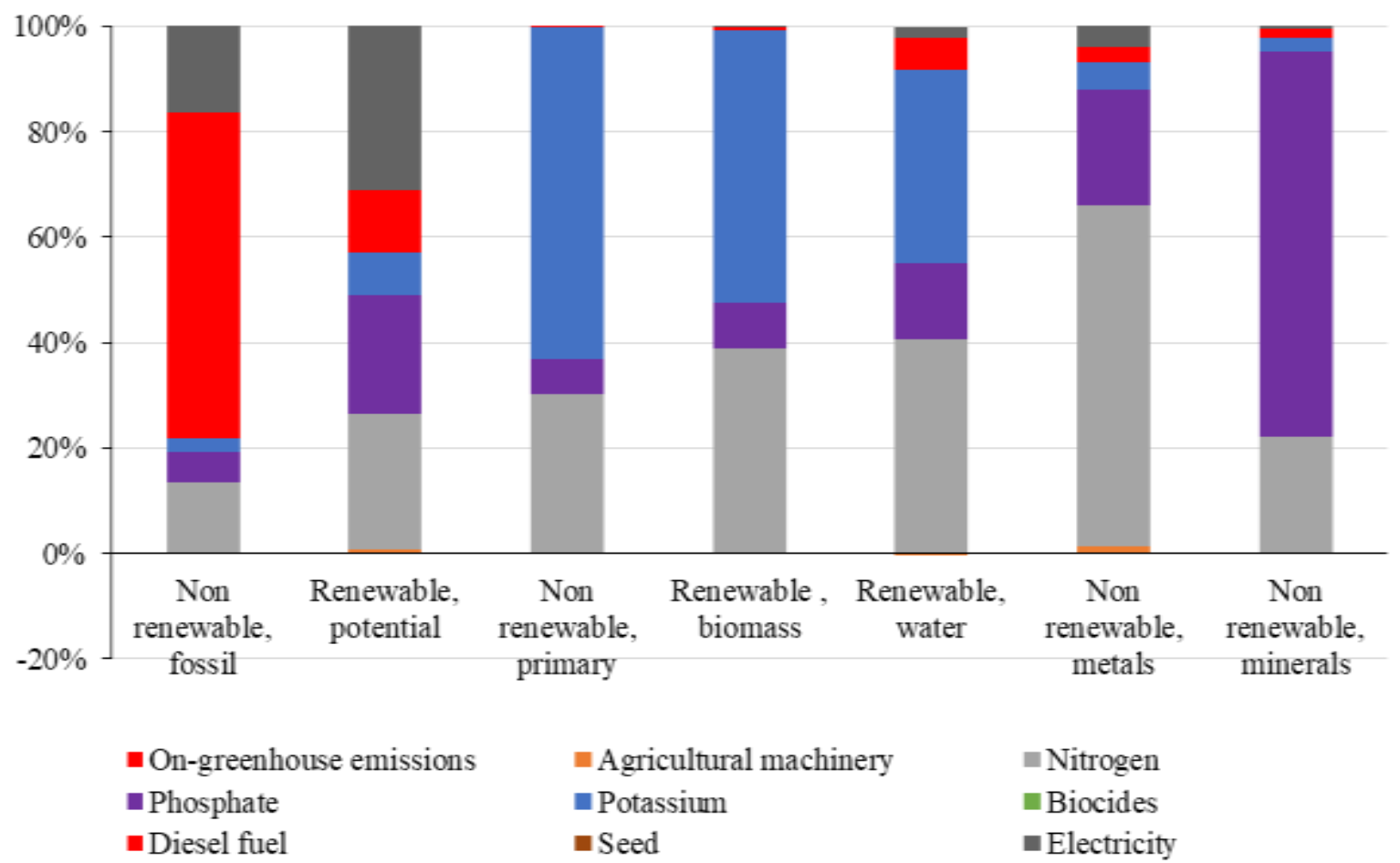

Fig. 8. Contribution of inputs to consume energy forms of cucumber and tomato production.

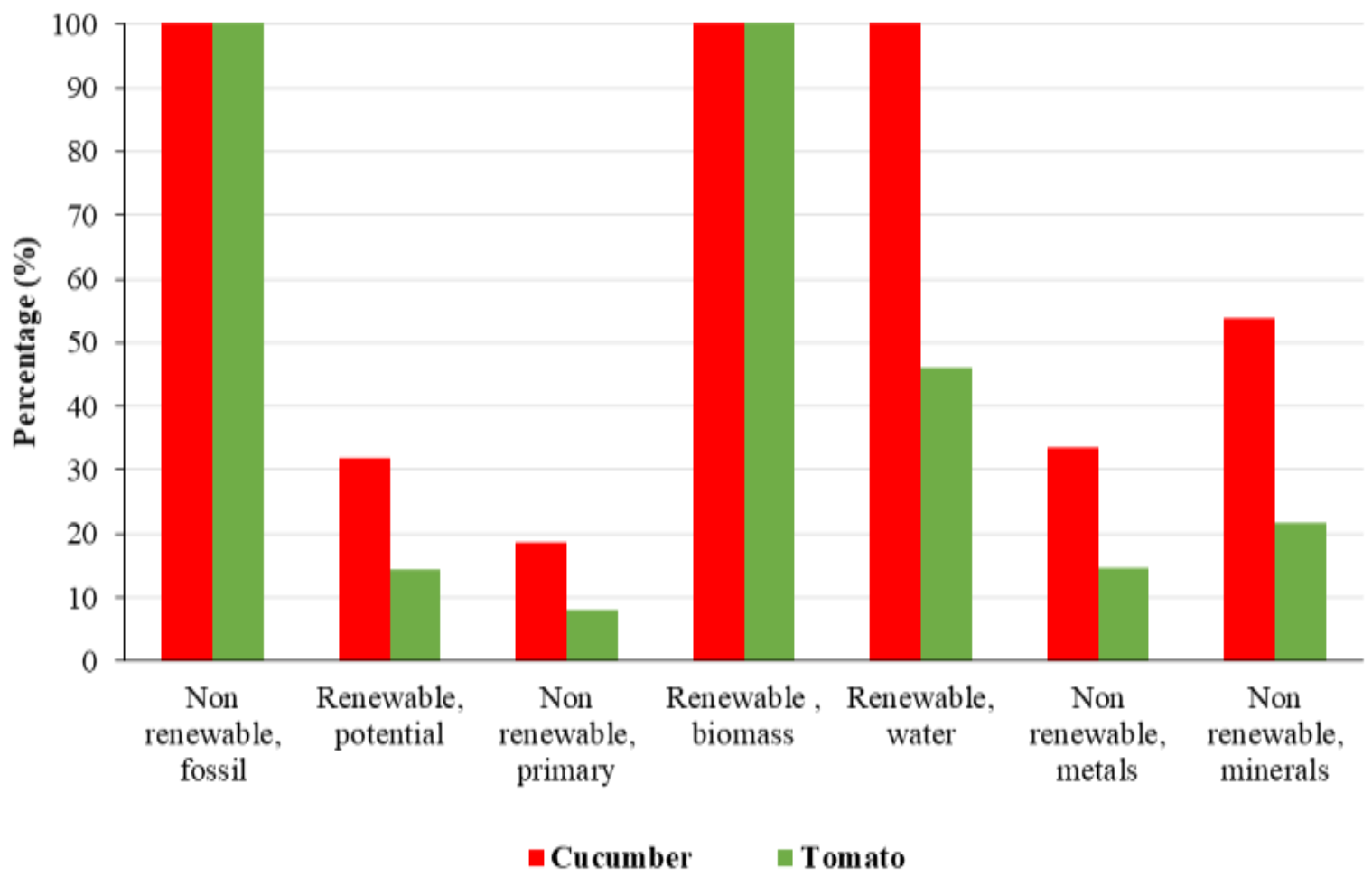

Fig. 9. Comparison between energy forms of cucumber and tomato production. 


\section{Conclusions}

The development of greenhouses has increased the need for energy. The main energy consumption in greenhouses is to heat the greenhouse space in the cold months and air conditioning in the warm seasons. However, costs such as supplementary lighting, automation system equipment and agricultural machinery should also be considered. Limited fossil fuels and environmental pollution from their consumption and rising global raw oil prices have necessitated the replacement of other renewable energy sources. In this study, diesel fuel has the highest energy consumption in the production of greenhouse cucumber and tomato. The energy forms obtained from the cumulative exergy demand method also result from the use of chemical fertilizers. Due to greenhouse cultivation in a closed and controllable environment, the ecosystem category obtained by LCA method had the lowest emissions. In environmental analyzes, diesel fuel also produces significant emissions. Optimal use of energy consumption in terms of plant physiology and technical aspects, design and technical equipment used in the greenhouse are discussed. Some energy sources such as solar, geothermal energy, industrial waste and agricultural products are essential to replace fossil fuels in greenhouse energy. According to the design principles, structure, location and common coverings in greenhouses, the necessary solutions to reduce energy consumption for each area should be provided. The design of greenhouse systems with high production capacity, minimum energy consumption and reduction of chemical fertilizers should be considered. Food safety is ensured in creating sustainable ecosystems.

\section{References}

(SAIC) SAIC (2006) Life-cycle assessment: principles and practice

Alam, M. Shahid, M. R. Alam and KKI (2005) Energy flow in agriculture: Bangladesh. Am J Environ Sci 1.3:213-220

Ali Q, Khan M, Research MK-A in E, 2017 undefined (2017) Impact of energy efficiency 
improvement on greenhouse gas in off-season tomato farming: Evidence from Punjab, Pakistan. techno-press.org 5:207-217.

Antón A, Torrellas M, Núñez M, et al (2014) Improvement of Agricultural Life Cycle Assessment Studies through Spatial Differentiation and New Impact Categories: Case Study on Greenhouse Tomato Production. Environ Sci Technol 48:9454-9462.

Bösch ME, Hellweg S, Huijbregts MAJ, Frischknecht R (2007) Applying cumulative exergy demand (CExD) indicators to the ecoinvent database. Int J Life Cycle Assess 12:181

Bosona T, Gebresenbet G (2018) Life cycle analysis of organic tomato production and supply in Sweden. J Clean Prod 196:635-643.

Brentrup F, Küsters J, Lammel J, et al (2004) Environmental impact assessment of agricultural production systems using the life cycle assessment (LCA) methodology II. The application to $\mathrm{N}$ fertilizer use in winter wheat production systems. Eur $\mathrm{J}$ Agron 20:265-279

Canakci M, Akinci I (2006) Energy use pattern analyses of greenhouse vegetable production. Energy 31:1243-1256

Cellura M, Longo S, Mistretta M (2012) Life Cycle Assessment (LCA) of protected crops: an Italian case study. J Clean Prod 28:56-62.

Cochran WG (1977) The estimation of sample size. Sampl Tech 3:72-90

Coltro L, Mourad A, Oliveira P, et al (2006) Environmental Profile of Brazilian Green Coffee (6 pp). Int J Life Cycle Assess 2006111 11:16-21.

Dalgaard T, Halberg N, Porter JR (2001) A model for fossil energy use in Danish agriculture used to compare organic and conventional farming. Agric Ecosyst Environ 87:51-65.

de Backer E, Aertsens J, Vergucht S, Steurbaut W (2009) Assessing the ecological soundness of organic and conventional agriculture by means of life cycle assessment (LCA): A case study of leek production. Br Food J 111:1028-1061. 
Demircan V, Ekinci K, Keener HM, et al (2006) Energy and economic analysis of sweet cherry production in Turkey: A case study from Isparta province. Energy Convers Manag 47:1761-1769.

Dewulf J, Bösch ME, Meester B De, et al (2007) Cumulative Exergy Extraction from the Natural Environment (CEENE): a comprehensive Life Cycle Impact Assessment method for resource accounting. Environ Sci Technol 41:8477-8483.

Edenhofer O (2015) Climate change 2014: mitigation of climate change

Esengun K, Erdal G, Gündüz O, Erdal H (2007) An economic analysis and energy use in stake-tomato production in Tokat province of Turkey. Renew Energy 32:1873-1881.

Gallego A, Hospido A, Moreira MT, Feijoo G (2011) Environmental assessment of dehydrated alfalfa production in Spain. Resour Conserv Recycl 55:1005-1012.

Ghasemi-Mobtaker H, Akram A, Keyhani A, Mohammadi A (2012) Optimization of energy required for alfalfa production using data envelopment analysis approach. Energy Sustain Dev 16:242-248

Ghasemi-Mobtaker H, Kaab A, Rafiee S (2020) Application of life cycle analysis to assess environmental sustainability of wheat cultivation in the west of Iran. Energy 193:116768.

Ghorbani R, Mondani F, Amirmoradi S, et al (2011) A case study of energy use and economical analysis of irrigated and dryland wheat production systems. Appl Energy $88: 283-288$.

Guinée JB (2002) Handbook on life cycle assessment operational guide to the ISO standards. Int J life cycle Assess 7:311

Hatirli SA, Ozkan B, Fert C (2006a) Energy inputs and crop yield relationship in greenhouse tomato production. Renew Energy 31:427-438.

Hatirli SA, Ozkan B, Fert C (2006b) Energy inputs and crop yield relationship in greenhouse tomato production. Renew Energy 31:427-438 
Heydari, B., Jafari, A., Rafiee, S., Ahmad, A. H., Sharifi, M., Yousefi, M., \& Mazaheri A (2015) Energy and Economic Analysis of Spearmint Essential Oil Production: a Case Study-Golkaran Agro-Industrial Co. J Agric Eng Biote 3(1):11

Hischier R, Nowack B, Gottschalk F, et al (2015) Life cycle assessment of façade coating systems containing manufactured nanomaterials. J Nanoparticle Res 17:68

IPCC (2006) 2006 IPCC guidelines for national greenhouse gas inventories. 2. Inst. Glob. Environ. Strateg. Hayama, Japan 48-56

ISO (2006) 14040 International standard. Environmental Management-Life Cycle Assessment-Principles and Framework, International Organisation for Standardization, Geneva, Switzerland.

Jones CD, Fraisse CW, Ozores-Hampton M (2012) Quantification of greenhouse gas emissions from open field-grown Florida tomato production. Agric Syst 113:64-72.

Kaab A, Sharifi M, Mobli H, et al (2019) Combined life cycle assessment and artificial intelligence for prediction of output energy and environmental impacts of sugarcane production. Sci Total Environ 664:1005-1019

Khanali M, Shahvarooghi Farahani S, Shojaei H, Elhami B (2017) Life cycle environmental impacts of saffron production in Iran. Environ Sci Pollut Res 24:4812-4821.

Khoshnevisan B, Rafiee S, Mousazadeh H (2013) Environmental impact assessment of open field and greenhouse strawberry production. Eur J Agron 50:29-37.

Khoshnevisan B, Rafiee S, Omid M, et al (2014a) Environmental impact assessment of tomato and cucumber cultivation in greenhouses using life cycle assessment and adaptive neuro-fuzzy inference system. J Clean Prod 73:183-192.

Khoshnevisan B, Shariati HM, Rafiee S, Mousazadeh H (2014b) Comparison of energy consumption and GHG emissions of open field and greenhouse strawberry production. Renew Sustain Energy Rev 29:316-324 
Longo S, Mistretta M, Guarino F, Cellura M (2017) Life Cycle Assessment of organic and conventional apple supply chains in the North of Italy. J Clean Prod 140:654-663.

Martin-Gorriz B, Soto-García M, Martínez-Alvarez V (2014) Energy and greenhouse-gas emissions in irrigated agriculture of SE (southeast) Spain. Effects of alternative water supply scenarios. Energy 77:478-488. https://doi.org/10.1016/J.ENERGY.2014.09.031

Ministry of Jihad-e-Agriculture of Iran (2020) Annual Agricultural Statistics. www.maj.ir (in Persian).

Mohammadi-Barsari A, Firouzi S, Aminpanah H (2016) Energy-use pattern and carbon footprint of rain-fed watermelon production in Iran. Inf Process Agric 3:69-75. 1

Mohammadi A, Omid M (2010) Economical analysis and relation between energy inputs and yield of greenhouse cucumber production in Iran. Appl Energy 87:191-196.

Mostashari-Rad F, Nabavi-Pelesaraei A, Soheilifard F, et al (2019) Energy optimization and greenhouse gas emissions mitigation for agricultural and horticultural systems in Northern Iran. Energy.

Mouron P, Nemecek T, Scholz RW, Weber O (2006) Management influence on environmental impacts in an apple production system on Swiss fruit farms: Combining life cycle assessment with statistical risk assessment. Agric Ecosyst Environ 114:311322.

Mousavi-Avval SH, Rafiee S, Jafari A, Mohammadi A (2011) Improving energy use efficiency of canola production using data envelopment analysis (DEA) approach. Energy 36:2765-2772

Nabavi-Pelesaraei A, Rafiee S, Hosseinzadeh-Bandbafha H, Shamshirband S (2016) Modeling energy consumption and greenhouse gas emissions for kiwifruit production using artificial neural networks. J Clean Prod 133:924-931.

Nemecek T, Kägi T, Blaser S (2007) Life cycle inventories of agricultural production 
systems. Final Rep ecoinvent v2 0 No 15:

Ozkan B, Akcaoz H, Karadeniz F (2004) Energy requirement and economic analysis of citrus production in Turkey. Energy Convers Manag 45:1821-1830

Ozkan B, Ceylan RF, Kizilay H (2011) Energy inputs and crop yield relationships in greenhouse winter crop tomato production. Renew Energy 36:3217-3221.

Ozkan B, Fert C, Karadeniz CF (2007) Energy and cost analysis for greenhouse and openfield grape production. Energy 32:1500-1504

Paramesh V, Arunachalam V, Nikkhah A, et al (2018) Optimization of energy consumption and environmental impacts of arecanut production through coupled data envelopment analysis and life cycle assessment. J Clean Prod 203:674-684.

Pirlo G, Carè S, Fantin V, et al (2014) Factors affecting life cycle assessment of milk produced on 6 Mediterranean buffalo farms. J Dairy Sci 97:6583-6593.

Pishgar-Komleh SH, Keyhani A, Rafiee SH, Sefeedpary P (2011) Energy use and economic analysis of corn silage production under three cultivated area levels in Tehran province of Iran. Energy 36:3335-3341

Pishgar-Komleh SH, Omid M, Heidari MD (2013) On the study of energy use and GHG (greenhouse gas) emissions in greenhouse cucumber production in Yazd province. Energy 59:63-71

Reganold JP, Glover JD, Andrews PK, Hinman HR (2001) Sustainability of three apple production systems. Nat 20014106831 410:926-930. https://doi.org/10.1038/35073574

Romero-Gámez M, Audsley E, Suárez-Rey EM (2014) Life cycle assessment of cultivating lettuce and escarole in Spain. J Clean Prod 73:193-203.

Ruviaro CF, Gianezini M, Brandão FS, et al (2012) Life cycle assessment in Brazilian agriculture facing worldwide trends. J Clean Prod 28:9-24.

Saber Z, Esmaeili M, Pirdashti H, et al (2020) Exergoenvironmental-Life cycle cost analysis 
for conventional, low external input and organic systems of rice paddy production. $\mathbf{J}$ Clean Prod 263:121529.

Sanjuán N, Úbeda L, Clemente G, et al (2005) LCA of integrated orange production in the Comunidad Valenciana (Spain). Int J Agric Resour Gov Ecol 4:163-177.

Sartori L, Basso B, Bertocco M, Oliviero G (2005) Energy Use and Economic Evaluation of a Three Year Crop Rotation for Conservation and Organic Farming in NE Italy. Biosyst Eng 91:245-256.

Singh H, Mishra D, Nahar NM (2002) Energy use pattern in production agriculture of a typical village in arid zone, India_- part I. Energy Convers Manag 43:2275-2286.

Taherzadeh-Shalmaei N, Sharifi M, Ghasemi-Mobtaker H, Kaab A (2021) Evaluating the energy use, economic and environmental sustainability for smoked fish production from life cycle assessment point of view (case study: Guilan Province, Iran). Environ Sci Pollut Res 1-14.

Taki M, Abdi R, Akbarpour M, Ghasemi-Mobtaker H (2013) Energy inputs - Yield relationship and sensitivity analysis for tomato greenhouse production in Iran. Agric Eng Int CIGR J 15:59-67

Unakitan G, Hurma H, Yilmaz F (2010) An analysis of energy use efficiency of canola production in Turkey. Energy 35:3623-3627.

Vinyes E, Asin L, Alegre S, et al (2017) Life Cycle Assessment of apple and peach production, distribution and consumption in Mediterranean fruit sector. J Clean Prod $149: 313-320$

Xue X, Hawkins TR, Ingwersen WW, Smith RL (2015) Demonstrating an approach for including pesticide use in life-cycle assessment: Estimating human and ecosystem toxicity of pesticide use in Midwest corn farming. Int J Life Cycle Assess 2015208 20:1117-1126. 
Yuan S, Peng S, Wang D, Man J (2018) Evaluation of the energy budget and energy use efficiency in wheat production under various crop management practices in China. Energy.

Zarei MJ, Kazemi N, Marzban A (2019) Life cycle environmental impacts of cucumber and tomato production in open-field and greenhouse. J Saudi Soc Agric Sci 18:249-255. 


\section{Supplementary Files}

This is a list of supplementary files associated with this preprint. Click to download.

- GRAPHICALABSTRACT.docx 